Article

\title{
Superoxide Scavenging Effects of Some Novel Bis-Ligands and Their Solvated Metal Complexes Prepared by the Reaction of Ligands with Aluminum, Copper and Lanthanum Ions
}

\author{
Shigeki Kobayashi * and Sachi Kanai \\ Division of Analytical Chemistry of Medicines, Showa Pharmaceutical University, \\ 3-3165 Higashitamagawagakuen, Machida, Tokyo 194-8543, Japan; \\ E-Mail: dog-rackykun6.santafe@docomo.ne.jp \\ * Author to whom correspondence should be addressed; E-Mail: kobayasi@ac.shoyaku.ac.jp; \\ Tel.: +81-42-721-1511; Fax: +81-42-721-1588.
}

Received: 4 March 2013; in revised form: 20 May 2013 / Accepted: 20 May 2013 /

Published: 23 May 2013

\begin{abstract}
Novel antioxidants have been synthesized and characterized by their chemical properties as antioxidants with high superoxide scavenging activity. $(2 R, 3 R)$ diphenylethylenediamine is a spacer in antioxidants, and we synthesized targets 11a and 11b by conjugation with $o$-hydroquinone and $p$-hydroquinone at the two $\mathrm{N}$-termini, respectively. Superoxide scavenging activities of the plant flavonoid-like 11a and 11b were compared with those of known antioxidants, and shown to increase in the following order: curcumin $<<$ ascorbic acid $<$ Trolox $<(+)$-epicatechin $<\mathbf{1 1 a}<$ quercetin $\leq \mathbf{1 1 b}$. Compound 11a also formed a solvated 11a-metal complex with metal ions. The 11a- $\mathrm{Cu}^{2+}$ complex was shown to have higher superoxide scavenging activity than that of $\mathbf{1 1 a}, \mathbf{1 1 b}, \mathrm{Cu}^{2+}$, and the $11 \mathrm{a}-\mathrm{Al}^{3+}$ and 11a- $\mathrm{La}^{3+}$ complexes, whereas the $11 \mathrm{a}-\mathrm{Al}^{3+}$ complex increased rather than decreased superoxide levels. The 11a- $\mathrm{Al}^{3+}$ complex did not abstract one electron from the SOMO of $\mathrm{O}_{2}^{-\cdot}$ since the HOMO and LUMO phases of $\mathrm{Al}^{3+}$ do not exist in the center of the $11 \mathrm{a}-\mathrm{Al}^{3+}$ complex. However, the SOMO of the 11a-Cu ${ }^{2+}$ complex distributed in the center of $\mathrm{Cu}^{2+}$ may abstract one electron from the SOMO of $\mathrm{O}_{2}^{-\cdot}$. These results suggest that 11a and 11b are powerful antioxidants.
\end{abstract}

Keywords: superoxide; catechol; $p$-hydroquinone; antioxidants; density functional theory; aluminum; copper; lanthanum; solvated metal complexes 


\section{Introduction}

Superoxide $\left(\mathrm{O}_{2}^{-\cdot}\right)$ and the hydroxyl radical $\left(\mathrm{OH}^{\cdot}\right)$ are produced by the reduction of $\mathrm{O}_{2}$ and have doublet spin multiplicity. These radicals are highly reactive and cause oxidative damage by the abstraction of an electron or $\mathrm{H}$ radical from biomolecules, especially proteins, lipids, and DNA. The excessive production of reactive oxygen species (ROS) in the body may be the most dangerous factor of many diseases such as inflammation, diabetes, cancer, aging, and neurodegenerative diseases including Parkinson's and Alzheimer's diseases [1,2]. Therefore, in recent years, many studies have investigated how to protect against ROS-induced oxidative damage using natural antioxidants such as vitamin $\mathrm{E}$, vitamin $\mathrm{C}$, and plant products such as flavonoids [3-5]. Russo et al. compared radical scavenging activities using a correlation between $\mathrm{O}-\mathrm{H}$ bond dissociation enthalpy (BDE) and the ionization potential (Ip) for the mechanism of the free radical oxidation of flavonoids [6,7]. Reactions between the antioxidants and metal complexes of flavonoids and $\mathrm{OH}$ or $\mathrm{OOH}$ radicals have also been investigated using computational kinetics methods [8]. Moreover, the metal ion effect for the radical scavenging of catechin has been investigated by kinetics analyses using the stopped flow method [9]. However, the design and production of more effective synthesized antioxidants and antioxidative metal complexes with their related products are less challenging than those of natural antioxidants.

The electronic states and estimation of the scavenging activities of antioxidants [10,11], using absolute hardness $(\eta)$ and electronegativity $(\chi)$ based on the chemical hardness theory [12-14], are very important to consider for the design process of antioxidants. We paid particular attention to the catechol ring substituted at $\mathrm{C} 2$ of the $\mathrm{B}$ ring in flavonoids because our previous studies have shown that the catechol ring produces chemically soft flavonoids. Conjugation of the catechol ring increased the electron donation, $\eta$, and $\chi$ of flavonoids [10]. $p$-Hydroquinone is a likely catechol ring with a similar radical scavenging activity to catechol. In this study, the radical scavenging activities of natural products and the novel antioxidants, 11a and 11b, were estimated by a reaction with $\mathrm{O}_{2}^{-}$, which was yielded from the hypoxanthine (HPX)-xanthine oxidase (XOD) system. We showed that the $\mathrm{O}_{2}{ }^{-}$. scavenging activity of $\mathbf{1 1 a}$ and 11b was higher than that of ascorbic acid, (+)-epicatechin, curcumin, Trolox, catechol, and $p$-hydroquinone.

We previously reported the synthesis and chemical properties of the solved complex of bis(amino acid)catechol derivatives with lanthanoid $\left(\mathrm{Ln}^{3+}\right)$ ions $[11,15,16]$. We paid attention to the fact that $\mathrm{Al}^{3+}$ and $\mathrm{Cu}^{2+/+}$ ions, besides amyloid $\beta$ protein misfolding and self-assembly, are causative compounds of Alzheimer's disease [17,18]. To investigate the influence of metal ions and metal complexes on the production and elimination of ROS, we measured $\mathrm{O}_{2}^{-}$. scavenging ability through chelation since 11a could form metal complexes with $\mathrm{Al}^{3+}$ and $\mathrm{Cu}^{2+}$ ions. It has been suggested as the active site since the $11 \mathrm{a}-\mathrm{Al}^{3+}$ and 11a- $\mathrm{La}^{3+}$ complexes have no or less effective $\mathrm{O}_{2}{ }^{-\cdot}$ scavenging activity. However, we found that low concentrations of the $\mathrm{Al}^{3+}$ ion slightly accelerated the formation of $\mathrm{O}_{2}^{-} \cdot$ by binding with 11a.

To anticipate the strength of potency for the $\mathrm{O}_{2}{ }^{-}$scavenging activities of $\mathrm{Al}^{3+}, \mathrm{Cu}^{2+}$, and $\mathrm{La}^{3+}$, we discussed the electronic states of $\mathrm{Al}^{3+}, \mathrm{Cu}^{2+}, \mathrm{La}^{3+}, \mathbf{1 1 a}-\mathrm{Al}, 11 \mathbf{a}-\mathrm{Cu}$, and $11 \mathbf{a}-\mathrm{La}$ complexes using the chemical hardness theory described above. The absolute hardness of $\mathrm{Cu}^{2+}$ is smaller than that of the $\mathrm{Al}^{3+}$ and $\mathrm{La}^{3+}$ ions since the coordinates $\mathbf{r}(\chi, \eta)$ as the electronic structures of $\mathrm{Al}^{3+}, \mathrm{Cu}^{2+}$, and $\mathrm{La}^{3+}$ ions have been shown to be $\mathbf{r}(70.48,37.96), \mathbf{r}(25.55,4.7)$, and $\mathbf{r}(15.23,14.43)$, respectively, in a ground state $[10,11]$. A singly occupied molecular orbital (SOMO) of the $d$ orbital of $\mathbf{1 1 a}-\mathrm{Cu}^{2+}$ is widely 
distributed in the center of the metal ion. The 11a- $\mathrm{Cu}^{2+}$ complex easily abstracted an electron from $\mathrm{O}_{2}^{-} ;$therefore, we demonstrated that 11a, 11b, 12, 13 and the $11 \mathbf{a}-\mathrm{Cu}^{2+}$ complex are useful antioxidants.

\section{Results and Discussion}

\subsection{Antioxidant Activity of Several Natural Producuts}

$\mathrm{O}_{2}^{-}$. scavenging activity was determined from the half maximal inhibitory concentration ( $\mathrm{IC}_{50}$ ) by changes in the chemiluminescence (CL) response by the reaction of 2-methyl-6- $p$-methoxyphenyl ethynylimidazopyrazynone (MPEC) with the $\mathrm{O}_{2}^{-\cdot}$ produced from the HPX-XOD system [19]. The $\mathrm{IC}_{50}$ represents the $50 \%$ concentration point of the dose-response curve of CL responses with various concentrations of antioxidants. Figure 1A shows the dose-response curve for $\mathrm{O}_{2}{ }^{-}$scavenging measured at 7-8 points of a concentration range between 0.0 and $10^{-4} \mathrm{M}(\mathrm{mol} / \mathrm{L})$ of Trolox (1) and quercetin (2). Trolox is a well-known antioxidant model of $d l$ - $\alpha$-tocopherol (vitamin E) [20]. In this experiment, relative $\mathrm{CL}$ intensity was about $20-30 \times 10^{6}$ relative chemiluminescence units (RLU). The $\mathrm{O}_{2}{ }^{-}$. scavenging activities of $\mathbf{1}$ and 2 were 64.7 and $8.8 \mu \mathrm{M}$. The activities of L-ascorbic acid (3), curcumin (5), and (+)-epicatechin (4) were 68.8, 708, and $21.1 \mu \mathrm{M}$, respectively, from the results obtained using the same experimental method. These results are summarized in Figure 1B. Antioxidative activities were shown to increase in the following order: $\mathbf{5}<\mathbf{3}<\mathbf{1}<\mathbf{4}<\mathbf{2}$ (Figure 1).

Figure 1. Dose-response curve of Trolox (1) and quercetin (2) on $\mathrm{O}_{2}^{-{ }^{-}}$scavenging inhibition (A) and the $\mathrm{IC}_{50}$ values of several antioxidants (B). All bars were expressed as the mean.

A

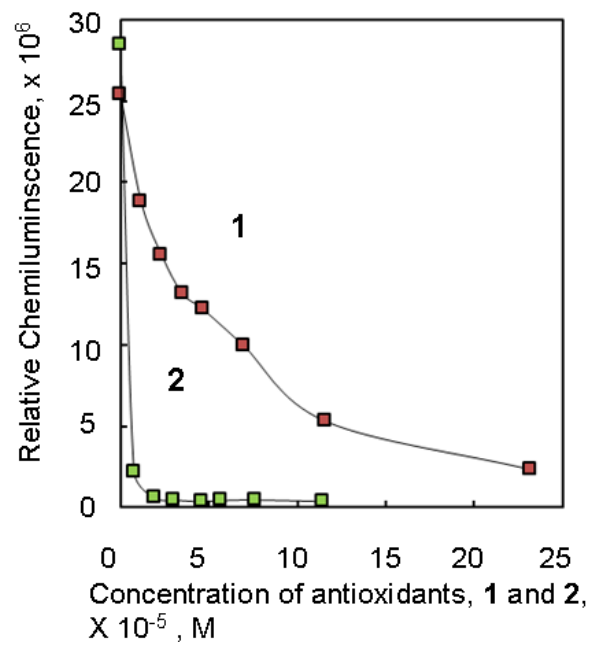

B

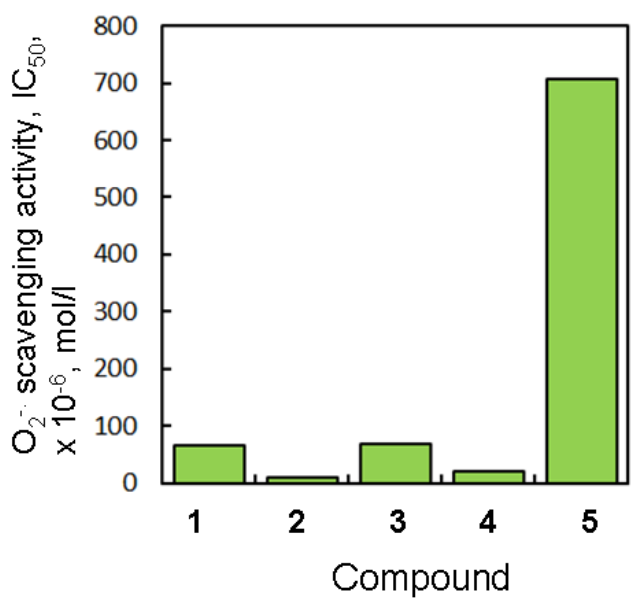

One of the reasons why curcumin has lower $\mathrm{O}_{2}{ }^{-}$scavenging activity than epicatechin is because the catecholic hydroxyl of curcumin protects the $\mathrm{CH}_{3}$ group. In the compounds tested in this study, the activity of quercetin was the most potent. The reason for this was the activity of the catechol ring. The catechol ring naturally binds at $\mathrm{C} 2$ in flavonoids such as quercetin, cyanidine, and rutin. Although flavonoids are expected to be natural products that provide powerful radical-scavenging activity, natural flavonoids in which the $p$-hydroquinone ring, a well-known regioisomer of catechol, binds to 
the flavonoid ring are almost unknown. The catechol and $p$-hydroquinone rings are useful in the development of new potent antioxidants.

\subsection{Synthesis and Stable Conformation of 11a and $\mathbf{1 1 b}$}

Interestingly, quercetin and epicatechin substituting catechol to the B ring of flavone and flavanone increased $\mathrm{O}_{2}^{-}$. scavenging activity and we designed targets 11a and 11b conjugated with two 2,3-bis(benzyloxy)benzoic acid (6) and 2,5-bis(benzyloxy)benzoic acid (7) units at the N-terminus of the $(1 R, 2 R)-(-)-1,2$-diphenylethylenediamine spacer, respectively, as shown in Scheme 1.

Scheme 1. Synthesis of the new antioxidants 11a and 11b.
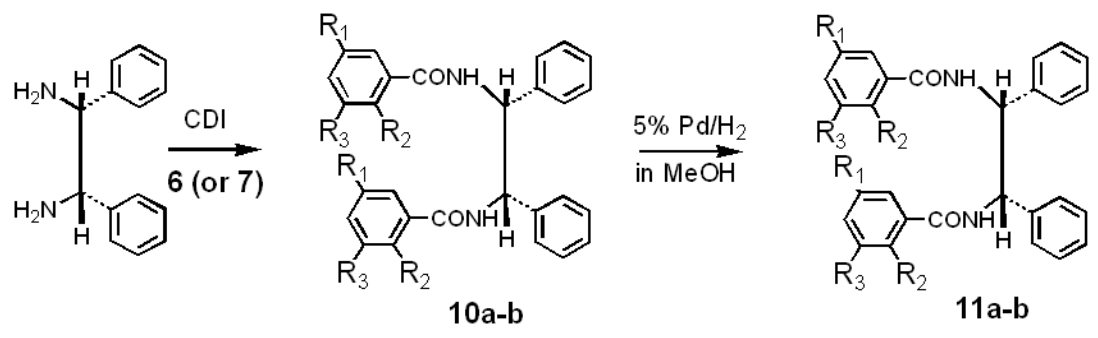

\begin{tabular}{cccc}
\cline { 2 - 3 } $10 \mathrm{a}$ & $\mathrm{R}_{1}$ & $\mathrm{R}_{2}$ & $\mathbf{R}_{3}$ \\
\cline { 2 - 4 } 10b & $\mathrm{H}$ & $\mathrm{OBz} z$ & $\mathrm{OBzl}$ \\
$11 \mathrm{a}$ & $\mathrm{H}$ & $\mathrm{OBzl}$ & $\mathrm{H}$ \\
$11 \mathrm{~b}$ & $\mathrm{OH}$ & $\mathrm{OH}$ & $\mathrm{H}$ \\
\hline
\end{tabular}

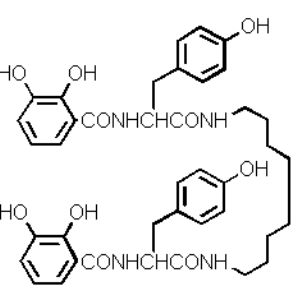

12

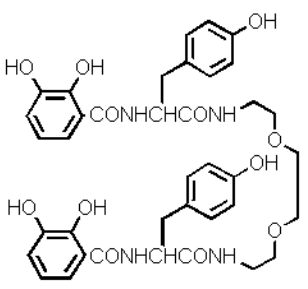

13

In particular, 2,5-bis(benzyloxy)benzoic acid was comparable to $p$-hydroquinone (8). Compound 11a, a derivative of catechol (9), was expected in the formation of a metal complex with metal ions [20,21]. Yields of 11a and 11b were lower than those of $\mathbf{1 2}$ and $\mathbf{1 3}$ due to the steric inhibition of 1,2-diphenyl groups. The crude compounds $\mathbf{1 0 a}$ and $\mathbf{1 0 b}$ were purified using column chromatography over neutral silica gel, respectively, and were recrystallized from methanol. After the purification of 10a and 10b, the benzyloxy protecting groups were removed with $\mathrm{H}_{2}$ and $5 \% \mathrm{Pd}-\mathrm{C}$ in methanol to yield the targets 11a (50\%) and 11b (55\%), respectively. Here, for example, compound $\mathbf{1 1 a}$ was purified by preparative thin layer chromatography (PTLC) using a silica gel plate with chloroform/MeOH (20:1) as mobile phase. Compounds 12 and 13 were synthesized following the same method as for 11a and 11b [10-12]. The compounds 11a, 11b, 12, and 13 provided satisfactory analysis by ${ }^{1} \mathrm{H}-\mathrm{NMR},{ }^{13} \mathrm{C}-\mathrm{NMR},{ }^{13} \mathrm{C}-{ }^{1} \mathrm{H}$ COSY NMR, and FAB-MS. The tyrosine (Y) $\alpha$ protons of 12 and $\mathbf{1 3}$ observed at $\delta 4.70$ and 4.74 are coupled with an amido proton at $\delta 8.49$ and 8.46 , respectively, and the observed ${ }^{3} \mathrm{~J}_{\alpha, \mathrm{NH}}$ values are 7.1-7.8 Hz. The values indicate that $\mathbf{1 2}$ and $\mathbf{1 3}$ provide a folded $\beta$-sheet like conformation [21]. Moreover, a very broad amido proton observed at $\delta 9.0$ may be consistent with an intramolecular hydrogen-bonded structure in double-strands of 13. On the other hand, 11a and 11b are assumed to have twist conformations since the half width values of $\mathrm{J}_{3 \mathrm{H}, \mathrm{NH}}$ of their amido protons were $<3 \mathrm{~Hz}$.

Compounds 11a and 11b had two catechol or $p$-hydroquinone rings in one molecule, respectively. When the $\mathrm{O}_{2}^{-\cdot}$ scavenging activities of $11 \mathbf{a}$ and $\mathbf{1 1 b}$ were compared with those of the catechol and $p$-hydroquinone rings, the potency of their activities was different. Compounds 11a and 11b had 
powerful antioxidant activity similar to quercetin and (+)-epicatechin. Hence, we estimated the conformation of 11a and 11b using a computational method by density functional theory (DFT). The most stable conformations of $\mathbf{1 1 a}$ and 11b were computed using conformation analysis with the MMFF method. Details of the conformation and electronic state were obtained after geometry optimization using B3LYP with a 6-31G(d) basis set and the B3LYP/6-31G(d) computed results are shown in Figure 3. The most stable structures of 11a and 11b in the gas phase are also shown in Figure 2. Total electron energy (E) was more stable in compound 11a $(-44689.83 \mathrm{eV})$ than in 11b $(-44689.64 \mathrm{eV})$. The two catechol rings of 11a faced each other. From this conformation, it is suggested that the four hydroxyl groups of 11a can easily form the metal chelator (Figure 2).

Figure 2. Most stable conformations after geometry optimization of 11a and 11b.

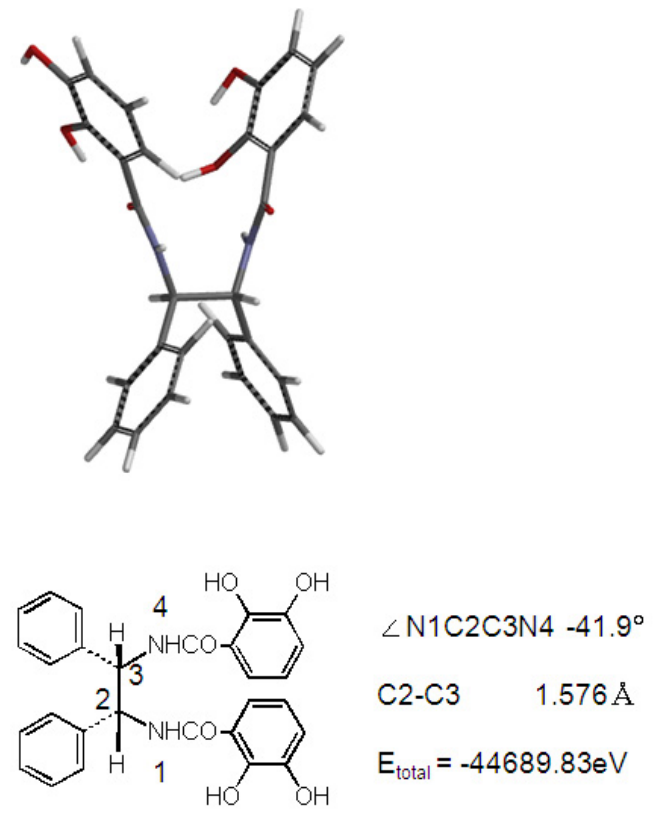

$11 \mathrm{a}$
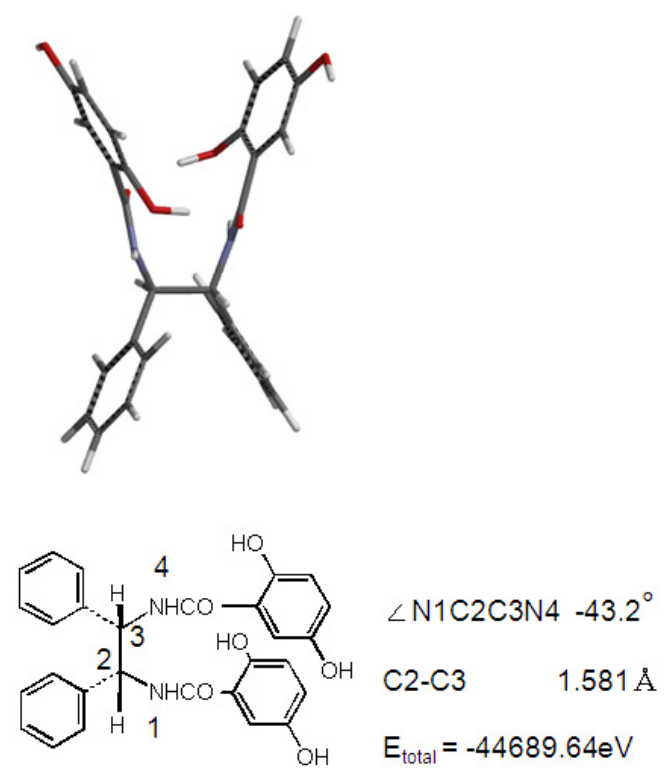

$11 \mathrm{~b}$

At B3LYP/6-31G(d) level; $\angle \mathrm{N} 1 \mathrm{C} 2 \mathrm{C} 3 \mathrm{~N} 4$ is the dihedral angle $\left(^{\circ}\right), \mathrm{C} 2-\mathrm{C} 3$ is bond length $(\AA)$, and $\mathrm{E}_{\text {total }}$ is total energy $(\mathrm{eV})$.

\subsection{Antioxidant Activity of $\mathbf{1 1 a}$ and $\mathbf{1 1 b}$}

Figure 3A shows the dose-responses curve of the CL responses obtained by the reaction of 11a and 11b with $\mathrm{O}_{2}^{-}$. Antioxidant activity was measured by the method described above. The results of $\mathrm{IC}_{50}$ (mean $\pm \mathrm{SD}$ ) are summarized in Figure $3 \mathrm{~B} \mathrm{O}_{2}{ }^{-} \cdot$ scavenging activity was stronger in compound $\mathbf{1 1 b}$ than in 11a. The $\mathrm{IC}_{50}$ value of $\mathbf{1 1 b}$ was $8.5( \pm 1.5) \mu \mathrm{M}$ and has higher $\mathrm{O}_{2}{ }^{-} \cdot$ scavenging activity than 11a $(20.0 \pm 5.0 \mu \mathrm{M})$, and inhibitory activity was higher in compounds 11a and 11b than in catechol and 8 alone. In particular, the $\mathrm{IC}_{50}$ of $\mathbf{1 1 b}$ conjugated 7 was about $1 / 2.5$ times that of 11a. $\mathrm{O}_{2}^{-} \cdot$ scavenging activity was also about four times higher by 11a than with 9 alone. On the other hand, the inhibitory activities of 12 and $\mathbf{1 3}$ were equal to or less than that of 7 (Figure 3C). They exhibited no effective $\mathrm{O}_{2}{ }^{-}$ scavenging activity relative to $\mathbf{1 1 a}$ and $\mathbf{1 1 b}$. However, compounds $\mathbf{1 2}$ and $\mathbf{1 3}$ had powerful antioxidant activities compared to $\mathbf{9}$ alone. 
Figure 3. Dose-response curve of the synthesized antioxidants 11a (A) and 11b (B) on $\mathrm{O}_{2}{ }^{-}$scavenging activity and the $\mathrm{IC}_{50}$ values of several antioxidants $(\mathbf{C})$.
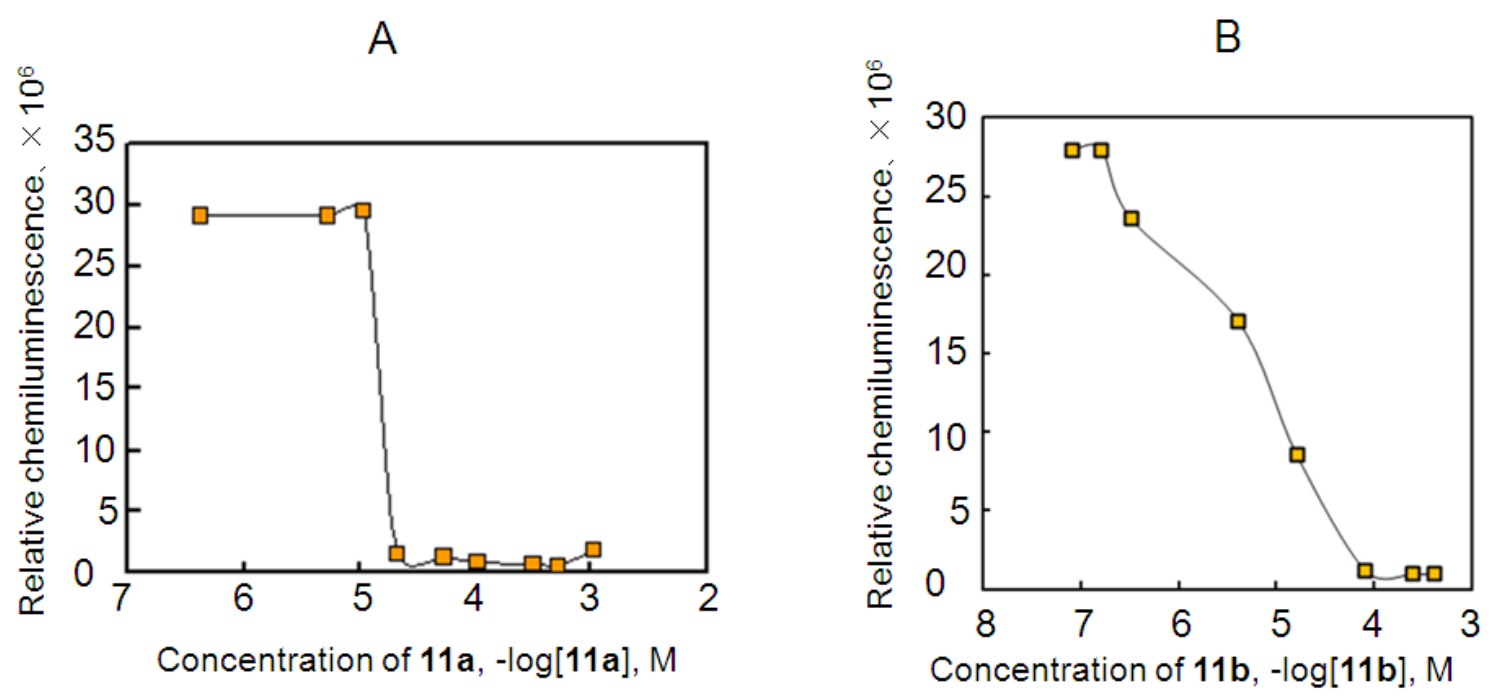

C

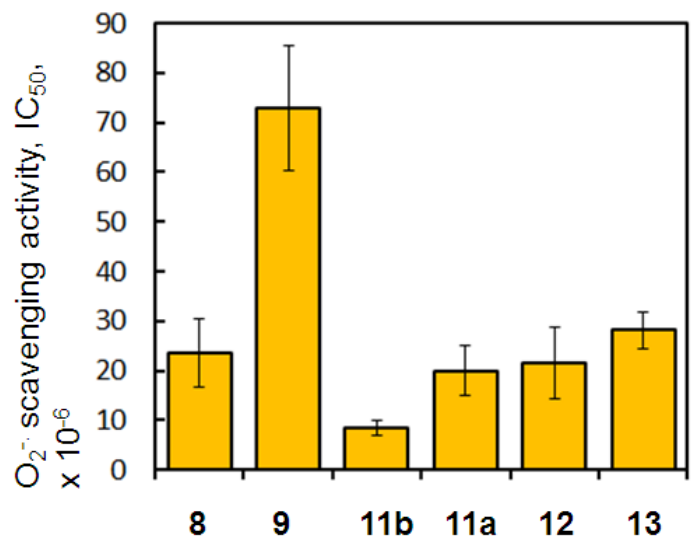

Incubation in $10 \mathrm{mM}$ phosphate buffer $\left(\mathrm{pH} \mathrm{7.5)}\right.$ for 2 min at $25{ }^{\circ} \mathrm{C}$; Responses were expressed as chemiluminescence for the concentration $(-\log [\mathrm{C}], \mathrm{M})$ of antioxidants 11a (A) and 11b (B); All bars were expressed as the mean \pm S.D. (C) 8: $p$-Hydroquinone, 9: catechol.

$\mathrm{O}_{2}{ }^{-}$scavenging activity was stronger in compounds $\mathbf{1 1 a}$ and $\mathbf{1 1 b}$ than in the natural compounds $\mathbf{1}$, $\mathbf{3}, \mathbf{4}$, and $\mathbf{5}$. The $\mathrm{IC}_{50}$ value of $\mathbf{1 1 b}$ was almost equal to that of quercetin $\mathbf{5}$. What are the chemical requirements that increase $\mathrm{O}_{2}^{-}$. scavenging activity? Differences in the spacers between 12, 13 and 11a, b affect inhibitory activity. In our previous study, we confirmed the relationship between the chemical hardness and antioxidant activity of antioxidants $[3,5]$. The chemical hardness concept can be applied to a comparison with the $\mathrm{O}_{2}{ }^{-}$scavenging power of antioxidants. By an MO calculation using B3LYP/6-31G(d), 11a $(\chi=3.565)$ and 11b $(\chi=3.480)$ had low absolute hardness and absolute electronegativity. Electron donation was higher in compounds 11a and 11b, with the $\chi$ values of 11a and 11b being smaller than the $\chi$ values of $\mathbf{2}(\chi=3.635), 3(\chi=3.765), 4(\chi=2.720)$, and 5 $(\chi=3.825)$. Regarding the values for hardness, 11a $(\eta=2.215)$ and 11b $(\eta=2.340)$ were smaller than $\mathbf{1}(\eta=2.650), \mathbf{3}(\eta=2.785)$, and $\mathbf{4}(\eta=2.869)$, except for $\mathbf{2}(\eta=1.835)$ and $\mathbf{5}(\eta=1.836)$. The $\chi$ value of $11 \mathrm{~b}$ was smaller than that of 11a. Although compounds 2 and 5 have a high driving force, their $\chi$ 
values were larger than those of 11a and 11b. These findings indicate that electron rich $\mathbf{1 1 b}$ is more easily oxidized when scavenging $\mathrm{O}_{2}^{-}$than $1,2,3,4,5$, and $11 \mathrm{a}$.

\subsection{Antioxidant Activity of the Metal Complexes 11a-M $M^{n+}$}

Compound 11a forms 1:1 ratio solvated metal complexes with metal ions. To measure the $\mathrm{O}_{2}{ }^{-}$. scavenging activity of the metal complexes $11 a-\mathrm{M}^{\mathrm{n}+}$, the molar ratio of $\mathbf{1 1 a}$ to metal ions has to be $1: 1$ at any concentration. Therefore, we prepared the solvated $11 \mathbf{a}-\mathrm{M}^{\mathrm{n}+}$ complexes of 11a with the metal ions, $\mathrm{Al}^{3+}, \mathrm{Cu}^{2+}$, and $\mathrm{La}^{3+}$ ions, at several concentrations. Dose-chemical luminescence curves were obtained from the scavenging reaction of the $11 \mathbf{a}-\mathrm{M}^{\mathrm{n}+}$ complexes under a constant concentration of $\mathrm{O}_{2}^{-}$, as shown in Figure 4. Although a decrease in CL was not clearly observed with the $\mathrm{Al}^{3+}$ (curve B in Figure 4), $\mathrm{La}^{3+}$ (data not shown) ions, and 11a- $\mathrm{Al}^{3+}$ (curve $\mathrm{A}$ in Figure 4) with $\mathrm{O}_{2}^{-}$; a decrease in $\mathrm{CL}$ was seen in the scavenging reaction of the $\mathrm{Cu}^{2+}$ (data not shown) ion and $11 \mathrm{a}-\mathrm{Cu}^{2+}$ with $\mathrm{O}_{2}{ }^{-}$. (curve $\mathrm{C}$ in Figure 4). From these results, it was shown that $\mathrm{O}_{2}{ }^{-} \cdot$ scavenging activity increased in the following order: 11a- $\mathrm{Al}^{3+}<11 \mathbf{a}-\mathrm{La}^{3+}<<\mathbf{1 1} \mathbf{a}-\mathrm{Cu}^{2+}$ complexes, which indicates that $\mathrm{Al}^{3+}, \mathrm{Cu}^{2+}$, and $\mathrm{La}^{3+}$ ions were coordinated to the hydroxides of catechol rings since 11a provides strong $\mathrm{O}_{2}{ }^{-}$. scavenging activity, as shown in Figure 3. The complexes 11a- $\mathrm{Al}^{3+}$ and $11 \mathrm{a}-\mathrm{La}^{3+}$ also had lower $\mathrm{O}_{2}{ }^{-}$ scavenging activity. The sites of the scavenging reaction of 11a were shown to be the hydroxides of the catechol rings. However, the 11a- $\mathrm{Cu}^{2+}$ complex showed scavenging activity in spite of the coordination of 11 a with $\mathrm{Cu}^{2+}$ and the activity was higher than $\mathrm{Cu}^{2+}$ only at $\mathrm{pH}$ 7.4. In addition, we focused on the $\mathrm{Al}^{3+}$ ion, which has been implicated in Alzheimer's disease through the process of amyloid $\beta$ protein $(A \beta)$ aggregation and oxidative free radicals [22]. The results shown in Figure $4 \mathrm{~A}$ show that the $\mathrm{Al}^{3+}$ ion slightly accelerated the formation of $\mathrm{O}_{2}^{-} \cdot$ by interactions with $\mathbf{1 1 a} . \mathrm{Al}^{3+}-\mathbf{1 1 a}$ complexes may have acted as a $\mathrm{O}_{2}^{-} \cdot$ generator.

Figure 4. Dose-response curve of $\mathrm{Al}^{3+}, 11 \mathbf{a}-\mathrm{Al}^{3+}$ and $11 \mathbf{a}-\mathrm{Cu}^{2+}$ complexes on $\mathrm{O}_{2}^{-}$. scavenging activity.

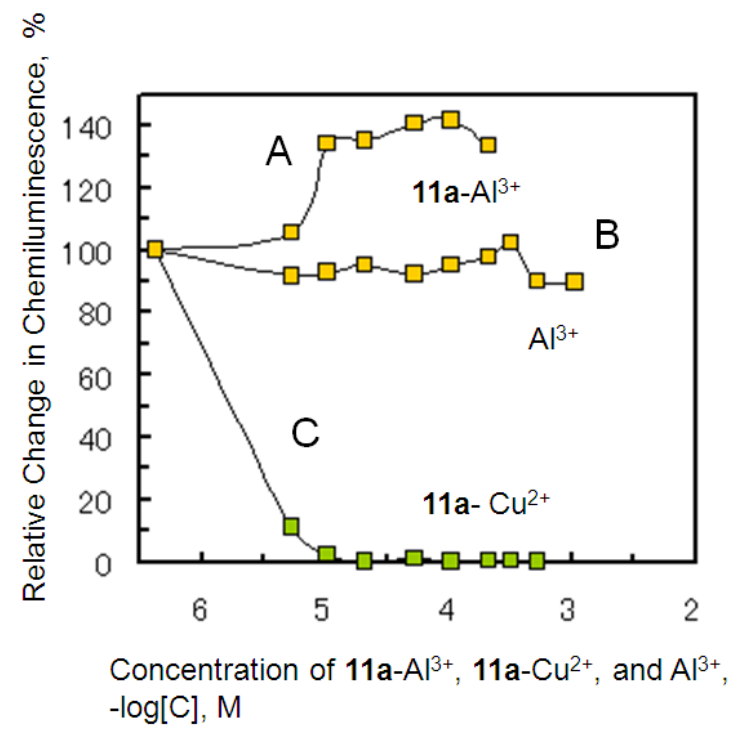

11a and the $\mathrm{Al}^{3+}$ and $\mathrm{Cu}^{2+}$ ions were mixed at a molar ratio of $1: 1$; The values of the $\mathrm{y}$-axis represent the relative changes in chemiluminescence as $\%$ inhibition. 
We prepared the solvated molecule complexes, 11a- $\mathrm{Al}^{3+}, \mathbf{1 1 a}-\mathrm{Cu}^{2+}$, and $11 \mathbf{a}-\mathrm{La}^{3+}$, with a molar ratio of $1: 1\left(=\left[\mathrm{M}^{\mathrm{n}+}\right]:[\mathbf{1 1 a}]\right)$ according to the method of our previous study based on UV/Vis spectrophotometry $[15,16]$. Structures were obtained after geometry optimization using the B3LYP method at a molar ratio of $1: 1$ of $\mathrm{M}^{\mathrm{n}+}$ and 11a; the 6-31G(d) basis set was used for $\mathrm{C}, \mathrm{H}, \mathrm{N}, \mathrm{Al}^{3+}$, and $\mathrm{Cu}^{2+}$, and the LANL2DZ basis set was used for optimization of the $\mathrm{La}^{3+}$ ion. Geometry optimized structures are shown in Figure 5. The atomic radii of $\mathrm{Al}^{3+}$ and $\mathrm{Cu}^{2+}$ ions were almost equal at 1.18 and $1.17 \AA$. Lanthanum (La) was $1.69 \AA$. These atomic radii were suitable to form the chelators of 11a with $\mathrm{Al}^{3+}, \mathrm{Cu}^{2+}$, and $\mathrm{La}^{3+}$ ions.

Figure 5. Most stable conformation of the 11a-metal ion complexes after geometry optimization.

A

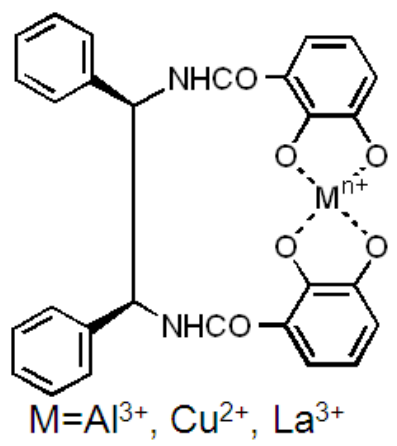

C

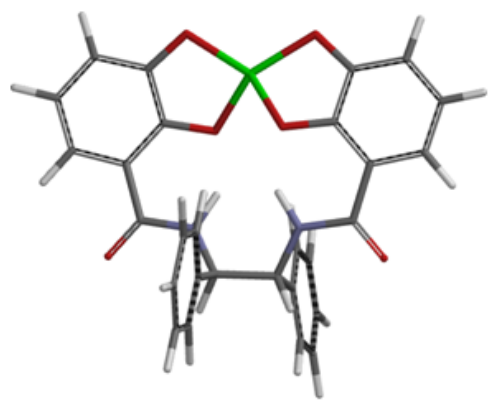

$11 \mathrm{a}-\mathrm{Cu}^{2+}$

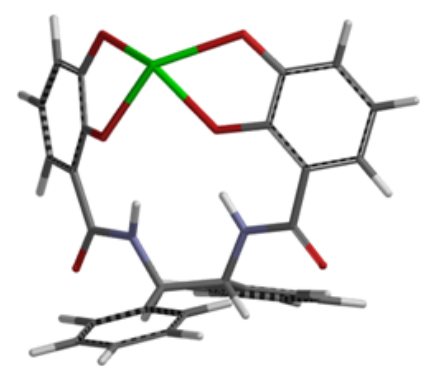

11a-La ${ }^{3+}$
B

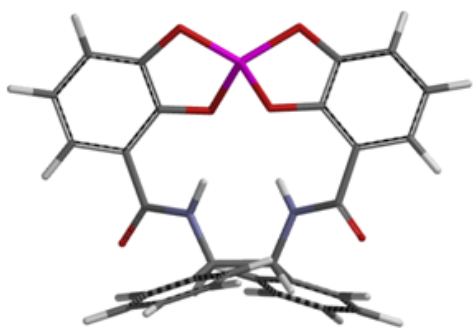

$11 \mathrm{a}-\mathrm{A} \mathrm{I}^{3+}$

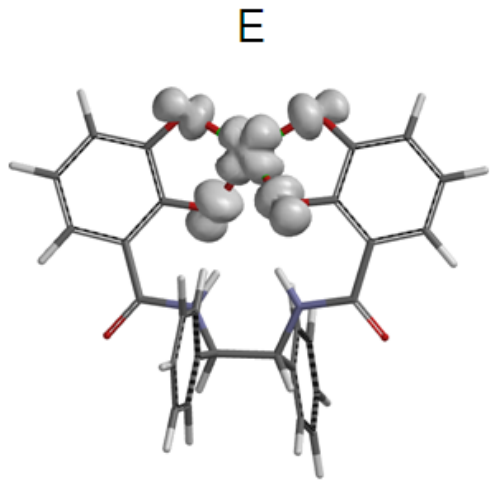

Spin density $\left(11 \mathrm{a}-\mathrm{Cu}^{2+}\right)$

The chemical structure of the 11a-metal ion complexes (A). Metal $\left(\mathrm{M}^{\mathrm{n}+}\right)=\mathrm{Al}^{3+}, \mathrm{Cu}^{2+}$, and $\mathrm{La}^{3+}$ ions; Most stable conformation of the 11a- $-\mathrm{M}^{\mathrm{n}+}$ complexes (B, C, and D): (i) $\mathrm{M}=\mathrm{Al}^{3+}$; (ii) $\mathrm{M}=\mathrm{Cu}^{2+}$; (iii) $\mathrm{M}=\mathrm{La}^{3+}$; Spin density map of the 11a-Cu ${ }^{2+}$ complex (E). At the B3LYP/6-31G(d) level.

Why the $11 \mathbf{a}-\mathrm{Al}^{3+}$ complex did not have $\mathrm{O}_{2}^{-} \cdot$ scavenging activity was considered using molecular orbitals. Lebedev et al. reported that excess $\mathrm{Ca}^{2+}$ increased the rate of catechol oxidation with $\mathrm{O}_{2}$ [23]. However, $\mathrm{Al}^{3+}$ alone did not increase $\mathrm{O}_{2}^{-} \cdot$ levels in our study (Figure 4). Asano demonstrated that porphyrin in the porphyrin- $\mathrm{Fe}^{\text {III }}$ complex was difficult to exchange to porphyrin- $\mathrm{Al}^{3+}$ by the coordination with $\mathrm{Al}^{3+}[24,25]$. In the HPX-XOD system, therefore, it is hard accepted that less $\mathrm{O}_{2}^{-}$. scavenging activity in the presence of $\mathrm{Al}^{3+}$ produced by $\mathrm{Al}-\mathrm{XOD}$, formed by the reaction of $\mathrm{Al}^{3+}$ with $\mathrm{Fe}-\mathrm{XOD} . \mathrm{O}_{2}^{-}$. produced by the HPX-XOD system is expected to interact with $\mathrm{Al}^{3+}$ in the center of the 11a- $\mathrm{Al}^{3+}$ complex. To understand the mechanism by which $\mathrm{Al}^{3+}$ in the 11a- $\mathrm{Al}^{3+}$ complex inhibits the $\mathrm{O}_{2}{ }^{-}$scavenging reaction, we theoretically analyzed an electronic energy diagram and molecular orbital of the geometry optimized 11a- $\mathrm{Al}^{3+}$ complex. The calculated bond lengths of $\mathrm{O}-\mathrm{Al}^{3+}, \mathrm{O}-\mathrm{Cu}^{2+}$ and 
$\mathrm{O}-\mathrm{La}^{3+}$ in the geometry optimized $11 \mathrm{a}-\mathrm{Al}^{3+}, \mathbf{1 1 a}-\mathrm{Cu}^{2+}$, and $11 \mathbf{a}-\mathrm{La}^{3+}$ complexes were $1.806,2.332$ and $2.349 \AA$, respectively, as displayed in Figure $5 . \mathrm{O}_{2}^{-} \cdot$ acted as an oxidant in the scavenging reaction with the $11 \mathbf{a}-\mathrm{Al}^{3+}, \mathbf{1 1} \mathbf{a}-\mathrm{Cu}^{2+}$, and $\mathbf{1 1} \mathbf{a}-\mathrm{La}^{3+}$ complexes, respectively (Figure 6).

Figure 6. Orbital energy level and the HOMO, SOMO, and LUMO phases of the optimized 11a-Metal complexes.

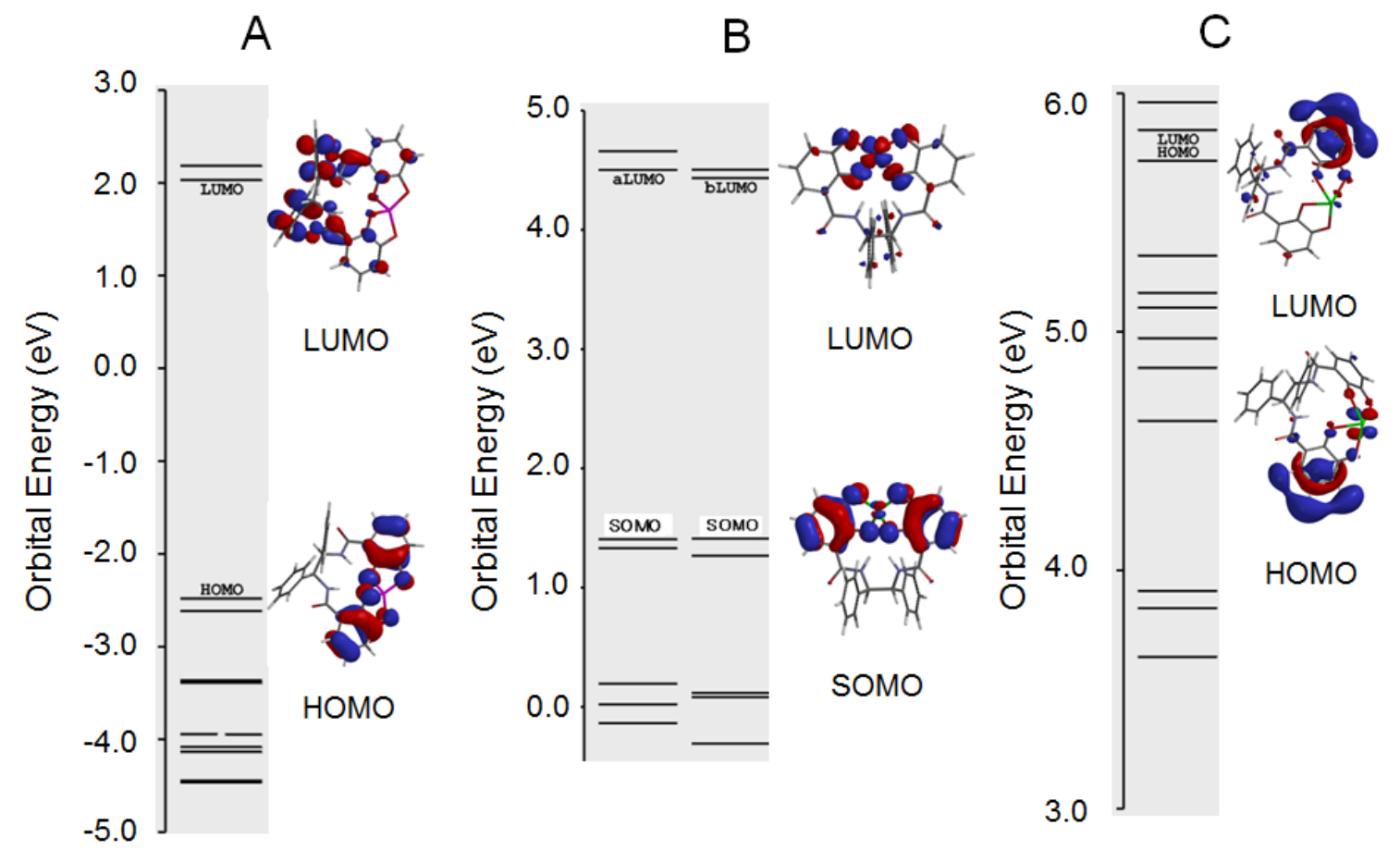

Orbital energy $(\mathrm{eV}), \varepsilon_{\text {homo }}, \varepsilon_{\text {lumo }}$, or $\varepsilon_{\text {somo }}$ of $11 \mathbf{a}-\mathrm{Al}^{3+}(\mathbf{A}), 11 \mathrm{a}-\mathrm{Cu}^{2+}(\mathbf{B})$, and $11 \mathbf{a}-\mathrm{La}^{3+}(\mathbf{C})$; At the B3LYP/6$31 \mathrm{G}(\mathrm{d})$ level for 11a- $\mathrm{Al}^{3+}\left(\varepsilon_{\text {homo }}=-2.48\right.$ and $\left.\varepsilon_{\text {lumo }}=2.03\right)$ and UB3LYP/6-31G(d) level for 11a- $\mathrm{Cu}^{2+}\left(\varepsilon_{\text {somo }}=1.41\right.$ and $\left.\varepsilon_{\text {lumo }}=4.50\right)$. At the B3LYP/lanL2DZ level for $11 \mathrm{a}^{-}-\mathrm{La}^{3+}\left(\varepsilon_{\text {homo }}=5.78\right.$ and $\left.\varepsilon_{\text {lumo }}=5.85\right)$.

In the scavenging reaction, $\mathrm{O}_{2}{ }^{-}$attacked the HOMO or SOMO of the metal-based MO in the $11 \mathbf{a}-\mathrm{M}^{\mathrm{n}+}$ complexes. The SOMO distribution of $\mathrm{Cu}^{2+}$ ions in the $11 \mathbf{a}-\mathrm{Cu}^{2+}$ complex was more widely distributed than that of the $\mathrm{Al}^{3+}$ and $\mathrm{La}^{3+}$ ions in the less active $11 \mathbf{a}-\mathrm{Al}^{3+}$ and $11 \mathbf{a}-\mathrm{La}^{3+}$ complexes, as shown in Figure 7. Moreover, the SOMO energy $\left(\varepsilon_{\text {somo }}=+1.41 \mathrm{eV}\right)$ of the $11 \mathrm{a}-\mathrm{Cu}^{2+}$ complex was significantly higher than that of the $11 \mathrm{a}-\mathrm{Al}^{3+}\left(\varepsilon_{\mathrm{homo}}=-2.48 \mathrm{eV}\right)$ and $11 \mathrm{a}-\mathrm{La}^{3+}\left(\varepsilon_{\mathrm{homo}}=+5.72 \mathrm{eV}\right)$ complexes. These results indicate the $11 \mathbf{a}-\mathrm{Cu}^{2+}$ complex was easily reduced to $11 \mathbf{a}-\mathrm{Cu}^{+}$. It is clear from this reason, therefore, that the value for the absolute hardness of $\mathrm{Cu}^{2+}$ was smaller than that for the $\mathrm{Al}^{3+}$ and $\mathrm{La}^{3+}$ ions since the coordinates $\mathbf{r}(\chi, \eta)$ for the electronic structures of $\mathrm{Al}^{3+}, \mathrm{Cu}^{2+}$, and $\mathrm{La}^{3+}$ ions were $\mathbf{r}(70.48,37.96), \mathbf{r}(25.55,4.7)$, and $\mathbf{r}(15.23,14.43)$, respectively, in the ground state [15,16]. The SOMO of the $d$ orbital of the $\mathrm{Cu}^{2+}$ ion in the $11 \mathrm{a}-\mathrm{Cu}^{2+}$ complex was more widely distributed in the center of the metal ion than that of the $\mathrm{Al}^{3+}$ and $\mathrm{La}^{3+}$ ions. The spin density of SOMO was presented in Figure 5E, where it was computed with B3LYP with 6-31G(d). 


\section{Experimental}

\subsection{Materials and Methods}

Pyrocatechol (2,3-dihydroxybenzoic acid), $p$-hydroquinone (2,5-dihydroxybenzoic acid), (1R,2R)(+)-diphenylethylenediamine, 2-amino-2-hydroxylmethyl-1,3-propanediol (Tris), $\mathrm{AlCl}_{3}$, copper(II) chloride $\cdot 2 \mathrm{H}_{2} \mathrm{O}\left(\mathrm{CuCl}_{2} \cdot 2 \mathrm{H}_{2} \mathrm{O}\right)$, and lanthanum chloride $\cdot 7 \mathrm{H}_{2} \mathrm{O}\left(\mathrm{LaCl}_{3} \cdot 7 \mathrm{H}_{2} \mathrm{O}\right)$ were purchased from Wako Pure Chemical Industries Ltd. (Osaka, Japan). XOD (from buttermilk, Lot. D00098728) and hypoxanthine (HPX) were obtained from Calbiochem (La Jolla, CA, USA). 2-Methyl-6-p-methoxyphenylethynylimidazo pyrazynone (MPEC) was purchased from Atto Corp. (Osaka, Japan). All experimental solutions were prepared with redistilled water. All other reagents were of the highest grade available. Compounds were detected on thin-layer chromatography (TLC) plates using iodine vapor or UV absorption. Silica gel column chromatography was performed on silica gel $60 \mathrm{~N}$ (100 mesh, neutral; Kanto Chemical Co., Tokyo, Japan). UV/vis spectra were measured with a JASCO V-530 spectrophotometer (JASCO Corp., Tokyo, Japan). Chemiluminescence was measured with a Lumat LB9507 (Berthold Technologies, Bad Wildbad, Germany). Nuclear magnetic resonance (NMR) spectra were obtained with a Bruker AV300 or AV600 spectrometer (Bruker Corp, Karlsruhe, Germany) and NMR samples were dissolved in $\mathrm{DMSO}_{6} / \mathrm{CDCl}_{3}$ (volume ratio = 5:2) with tetramethylsilane (TMS) as an internal reference. Fast atom bombardment mass (FAB) spectra were obtained on a JMS-HX110 spectrometer (JEOL Ltd., Tokyo, Japan), and relevant data were tabulated as $m / z$. Solvent systems were as follows, $\mathrm{A}: \mathrm{CHCl}_{3}-\mathrm{MeOH}(20: 1)$, and $\mathrm{B}: \mathrm{CHCl}_{3}-\mathrm{MeOH}(10: 1)$.

\subsection{Synthesis}

Compounds 12 and 13 were prepared by the method described in our previous studies [11]. 2,3-Bis(benzyloxy)benzoic acid (6) (1.84 g, $5.5 \mathrm{mmol})$ in dry $\mathrm{CHCl}_{3}(25 \mathrm{~mL})$ was added to CDI (1.13 g, $7.0 \mathrm{mmol})$ and stirred at room temperature for $1 \mathrm{~h}$. To this solution, $0.56 \mathrm{~g}(2.6 \mathrm{mmol})$ of $(1 R, 2 R)-(+)-$ diphenylethylenediamine was added, and the resulting mixtures were stirred overnight. The solvent was removed in an evaporator, and the residue was taken up in $\mathrm{CHCl}_{3}$, washed with $5 \% \mathrm{NaHCO}_{3}$, water, dried $\left(\mathrm{Na}_{2} \mathrm{SO}_{4}\right)$, and filtered. The crude residues were chromatographed on silica gel (40 g) with $\mathrm{CHCl}_{3}$ as an eluent. 10a was slightly soluble in $\mathrm{MeOH}$ and was recrystallized from hot MeOH. 10a was obtained as a colorless solid in $43.0 \%$ yield $(0.94 \mathrm{~g})$; m.p. $85-86{ }^{\circ} \mathrm{C}$ (from hot $\mathrm{MeOH}$ ). $\mathrm{R}_{\mathrm{f}}(\mathrm{A})=0.86$. High-resolution (HR)-FAB-MS ( $p$-nitrobenzoate(NBA)) $m / z: 845.3597$ (Calcd. for $\left.\mathrm{C}_{56} \mathrm{H}_{49} \mathrm{O}_{6} \mathrm{~N}_{2}: 845.3590[\mathrm{M}+\mathrm{H}]^{+}\right)$.

Five \% Pd-C (0.35 g) was added to a solution of 10a (1.76 g, $2.08 \mathrm{mmol})$ in $\mathrm{MeOH}(200 \mathrm{~mL})$. The mixture was shaken under a flow of $\mathrm{H}_{2}$. After the reaction was completed, the catalyst was removed with a glass filter (G3-4). The filtrate was suspended in aqueous $\mathrm{MeOH}$ and extracted several times with $\mathrm{CHCl}_{3}$. The organic layer was washed with $5 \% \mathrm{NaHCO}_{3}$ and the aqueous layer was neutralized with $0.1 \mathrm{M} \mathrm{HCl}$. The neutralized layers were extracted several times with $\mathrm{CHCl}_{3}$, washed with water, dried with $\mathrm{Na}_{2} \mathrm{SO}_{4}$, and filtered with a glass filter. The solvent was removed in the evaporator, and the solids were precipitated. The solids $(180 \mathrm{mg})$ were dissolved in $1 \mathrm{~mL} \mathrm{MeOH}$ and subjected to preparative thin layer chromatography (PTLC) using a $20 \times 20 \mathrm{~cm}$ silica gel $60 \mathrm{~F}_{254}$ plate $(2 \mathrm{~mm}$ thickness) (Merck Ltd., Whitehouse Station, NJ, USA) with chloroform/MeOH (20:1) as mobile phase. 
The disclosed bands of 11a were then scraped off, dissolved in chloroform/methanol mixture (1:1) and filtered with absorbent cotton. The solvent was removed by evaporation to give 11a as a yellowish brown powder. Yield 50\% (90 mg). $\mathrm{R}_{\mathrm{f}}(\mathrm{B})=0.57$. m.p. $173-175{ }^{\circ} \mathrm{C} .{ }^{1} \mathrm{H}-\mathrm{NMR}\left(\mathrm{DMSO}-d_{6} / \mathrm{CDCl}_{3}\right) \delta$ : $5.58(\mathrm{~d}, J=4.1 \mathrm{~Hz}, 1 \mathrm{H}), 6.58$ (t, $J=7.7 \mathrm{~Hz}$, catecholic protons), 6.87 (d, $J=7.4 \mathrm{~Hz}$, catecholic protons), 7.11-7.34 (m, 5H), 9.99 (broad, -NH-, 1H). ${ }^{13} \mathrm{C}-\mathrm{NMR}$ (DMSO- $d_{6} / \mathrm{CDCl}_{3}$ ) ppm: 58.75, 115.1, 116.5, 117.6, 117.9, 127.9, 128.0, 128.7, 139.1, 146.7, 151.3, and 170.1. HR-FAB-MS (NBA) $m / z: 485.1712$ (Calcd. for $\mathrm{C}_{28} \mathrm{H}_{25} \mathrm{O}_{6} \mathrm{~N}_{2}: 485.1713[\mathrm{M}+\mathrm{H}]^{+}$).

10b: prepared from 7 in a similar manner to that described for 10a. Yield 48\%. $\mathrm{R}_{\mathrm{f}}(\mathrm{A})$ 0.90. m.p. 106-107 ${ }^{\circ} \mathrm{C}$ (from hot MeOH). HR-FAB-MS (NBA) $m / z: 845.3599$ (Calcd. for $\mathrm{C}_{56} \mathrm{H}_{49} \mathrm{O}_{6} \mathrm{~N}_{2}: 845.3590$ $\left.[\mathrm{M}+\mathrm{H}]^{+}\right)$.

11b: prepared from 10a in a similar manner to that described for 11a. Yield 55\%. $\mathrm{R}_{\mathrm{f}}(\mathrm{B})$ 0.44. m.p. 170-171 ${ }^{\circ} \mathrm{C} .{ }^{1} \mathrm{H}-\mathrm{NMR}\left(\mathrm{DMSO}-d_{6} / \mathrm{CDCl}_{3}\right) \delta: 5.64(\mathrm{~d}, J=4.3 \mathrm{~Hz}, 1 \mathrm{H}), 6.68(\mathrm{~d}, J=8.8 \mathrm{~Hz}$, $p$-hydroquinone protons), 6.87 (dd, $J=2.8$ and $8.8 \mathrm{~Hz}, p$-hydroquinone protons), 7.14-7.37 (m, 5H), and 9.34 (broad, $-\mathrm{NH}-, 1 \mathrm{H}$ ). ${ }^{13} \mathrm{C}-\mathrm{NMR}$ (DMSO- $d_{6} / \mathrm{CDCl}_{3}$ ) ppm: 57.09, 112.9, 114.9, 117.5, 121.3, 1126.8, 126.9, 127.7, 139.4, 148.9, 152.6, and 168.7. HR-FAB-MS (NBA) m/z: 485.1707 (Calcd. for $\left.\mathrm{C}_{28} \mathrm{H}_{25} \mathrm{O}_{6} \mathrm{~N}_{2}: 485.1713[\mathrm{M}+\mathrm{H}]^{+}\right)$.

\section{3. $\mathrm{O}_{2}^{-} \cdot$ Scavenging Assay}

$\mathrm{O}_{2}^{-}$. was generated using the HPX-XOD system. $\mathrm{O}_{2}^{-\cdot}$ was subsequently emitted to reduce MPCE, which yielded a chemiluminescence product. The chemiluminescence concentration was measured as the chemiluminescence intensity (CL) with a lumicounter (Lumat LB9507, Berthold). XOD (0.1 U/mL) and HPX $(0.75 \mathrm{mM})$ were prepared with $0.1 \mathrm{M}$ phosphate buffer $(\mathrm{pH} 7.5)$. The $\mathrm{O}_{2}^{-}$scavenging reaction was performed in a total volume of $300 \mu \mathrm{L}$ at $25^{\circ} \mathrm{C}$ by mixing XOD $(60 \mu \mathrm{L}), 0.1 \mathrm{M}$ phosphate buffer (final concentration 0.01 M phosphate buffer), MPEC $(10 \mu \mathrm{L}, 300 \mathrm{mM})$, and $\operatorname{HPX}(50 \mu \mathrm{L})$. Test compounds were mixed in nine test tubes $(5 \mathrm{~mL})$ just before adding HPX and the final concentrations of the test compounds, 11a and 11b, were 0.043, 0.53, 1.07, 2.13, 5.33, 10.66, 32.0, 53.3, and $106.6 \times$ $10^{-5} \mathrm{M}$, respectively. The activities of compounds $\mathbf{1}, \mathbf{2}, \mathbf{3}, \mathbf{4}, \mathbf{5}, \mathbf{1 2}$, and 13 also were measured by a similar method.

A total of $0.01 \mathrm{M}$ phosphate buffer was added to the reaction solution to a final volume of $3 \mathrm{~mL}$ and the solution was mixed. The reaction mixtures were then incubated at $25{ }^{\circ} \mathrm{C}$ in a water bath for $2 \mathrm{~min}$. The reaction solution without test compounds was equilibrated to the desired level of CL output for $1 \mathrm{~min}$. The half-maximal inhibitory concentration $\left(\mathrm{IC}_{50}\right)$ was calculated from the dose-CL curve obtained from measured CL and the concentrations of the test compounds as shown in Figures 1 and 4.

\section{4. $\mathrm{O}_{2}^{-\cdot}$ Scavenging Assay of the 11a-Metal Ion Complexes and Metal Ions}

Solvated 11a-metal ion complexes were prepared from the reaction of $\mathbf{1 1 a}$ with $\mathrm{Al}^{3+}, \mathrm{Cu}^{2+}$, and $\mathrm{La}^{3+}$ ions, respectively, according to the UV/Vis titration method of previous studies $[15,16]$. Stock solutions of $3.2 \mathrm{mM}$ of $\mathbf{1 1 a}$ in $\mathrm{EtOH}$ and $2.89 \mathrm{mM}^{\circ} \mathrm{Al}^{3+}, \mathrm{Cu}^{2+}$, and $\mathrm{La}^{3+}$ ions in $10 \mathrm{mM}$ phosphate buffer ( $\mathrm{pH}$ 7.5) were prepared, and 11a and $\mathrm{Al}^{3+}, \mathrm{Cu}^{2+}$, and $\mathrm{La}^{3+}$ ions were mixed at a molar ratio of 
1:1, respectively. According to the method of the $\mathrm{O}_{2}^{-}$. Scavenging Assay, 11a-metal ion $\left(\mathrm{Al}^{3+}, \mathrm{Cu}^{2+}\right.$, and $\left.\mathrm{La}^{3+}\right)$ complexes were mixed with XOD $(0.1 \mathrm{U} / \mathrm{mL})$ in nine test tubes $(5 \mathrm{~mL})$ just before adding HPX and the final concentrations of the complexes were $0.038,0.53,1.06,2.12,5.30,10.60,21.2$, 31.8 , and $53.0 \times 10^{-5} \mathrm{M}$, respectively. The mixtures were incubated at $25{ }^{\circ} \mathrm{C}$ for $2 \mathrm{~min}$. Figure 5 shows the dose- $\mathrm{CL}$ curves of the $11 \mathrm{a}-$ metal ions $\left(\mathrm{Al}^{3+}\right.$ and $\left.\mathrm{Cu}^{2+}\right)$ complexes and $\mathrm{Al}^{3+}$ alone.

\subsection{Computational Chemistry}

Optimized conformations of the antioxidants and metal complexes in gas-phase were computed using the Spartan '10 (Wavefunction, Inc., Irvine, CA, USA) program. The lowest energy conformers determined with conformational search (Monte-Carlo method) computation at the MMFF94 level were optimized by the hybrid-density functional theory (DFT) using restricted B3LYP or unrestricted B3LYP functional with the split-valence $6-31 \mathrm{G}(\mathrm{d})$ basis set, and the results of the heavy atom 11a- $\mathrm{La}^{3+}$ complex were obtained using B3LYP methods with Los Alamos effective core potentials (ECP) plus the double zeta (DZ) functions (LanL2DZ) basis set [26]. The B3LYP functional with the 6-31G(d) basis set was used on all other atoms. The geometries and electronic energy of the $11 \mathbf{a}-\mathrm{Cu}^{2+}$ complex with a spin multiplicity ( $S$ ) of $S=2$ were computed using unrestricted B3LYP functional with the 6-31G(d) basis set. The zero-point and thermal corrections of 11a and 11b were obtained by a complete vibrational analysis using single points on the $6-31 \mathrm{G}(\mathrm{d})$ optimized structures.

\section{Conclusions}

We have demonstrated the synthesis and $\mathrm{O}_{2}{ }^{-} \cdot$ scavenging activity of some new potent antioxidants, 11a and 11b, conjugated with catechol and $p$-hydroquinone, and the solvated complexes, 11a- $\mathrm{Al}^{3+}$ and 11a- $\mathrm{La}^{3+}$, of 11a with the $\mathrm{Al}^{3+}$ and $\mathrm{La}^{3+}$ ions exhibited no scavenging activity; however, the $11 \mathbf{a}-\mathrm{Cu}^{2+}$ complex provided strong superoxide scavenging activity, which was more powerful than the $\mathrm{Cu}^{2+}$ ion alone. This was attributed to the spin multiplicity of the $11 \mathbf{a}-\mathrm{Cu}^{2+}$ complex being doublet and it having an $\varepsilon_{\text {SOMO }}$ of $+1.41 \mathrm{eV}$. The SOMO of the $11 \mathrm{a}-\mathrm{Cu}^{2+}$ complex was expanded in the center of the $\mathrm{Cu}^{2+}$ ion. The SOMO plays an important role in the superoxide scavenging activity of the $\mathbf{1 1 a}-\mathrm{Cu}^{2+}$ complex. The 11a- $\mathrm{Cu}^{2+}$ complex increased the chemical softness and decreased the absolute hardness. The electronic state of 11a contributed to the increase in chemical softness.

Although 11a- $\mathrm{Al}^{3+}$ had a small $\chi$ value, its $\eta$ value was 2.255 , which was smaller than that of $11 \mathrm{a}-\mathrm{Cu}^{2+}$. This finding indicates that it is difficult to act on as the driving force of the redox reaction. The HOMO distribution of the $11 \mathbf{a}-\mathrm{Al}^{3+}$ and $11 \mathrm{a}-\mathrm{La}^{3+}$ complexes was not in the metal center. In addition, the slight increase in $\mathrm{O}_{2}^{-}$by the $\mathbf{1 1} \mathbf{a}-\mathrm{Al}^{3+}$ complex indicated the important role of $\mathrm{Al}^{3+}$ in accelerating the formation of $\mathrm{O}_{2}^{-}$; which ultimately contributes to Alzheimer's disease through the process of oxidative free radicals. We showed the importance of the design of molecular and metal complexes using chemical hardness to control the antioxidant activity of $\mathrm{O}_{2}^{-}$; and developed the powerful antioxidants, 11a, 11b, 12, 13 and the solvated complex 11a- $\mathrm{Cu}^{2+}$ system.

\section{Conflict of Interest}

The authors declare no conflict of interest. 


\section{References}

1. Droge, W. Free radicals in the physiological control of cell function. Physiol. Rev. 2002, 82, 47-95.

2. Halliwell, B.; Cross, C.E. Oxygen-derived species: Their relation to human disease and environmental stress. Environ. Health Perspect. 1994, 102, 5-12.

3. Cos, P.; Ying, L.; Calomme, M.; Hu, J.P.; Cimanga, K.; Poel, V.B.; Piters, L.; Vlietick, A.J.; Berghe, D.V. Structure-activity relationships and classification of flavonoids as inhibitors of xanthine oxidase and superoxide scavengers. J. Nat. Prod. 1998, 61, 71-76.

4. Okawa, M.; Kinjo, J.; Nohara, T.; Ono, M. DPPH(1,1-diphenyl-2-picrylhydrazyl) radical scavenging activity of flavonoids obtained from some medicinal plants. Biol. Pharm. Bull. 2001, 24, 1202-1205.

5. Iwatsuki, M.; Tsuchiya, J.; Komuro, E.; Yamamoto, Y.; Niki, E. Effects of solvents and media on the antioxidant activity of $\alpha$-tocopherol. Biochim. Biophys. Acta 1994, 1200, 19-26.

6. Leopoldini, M.; Marino, T.; Russo, N.; Toscano, M. Antioxidant properties of phenolic compounds: H-atom versus electron transfer mechanism. J. Phys. Chem. A 2004, 108, 4916-4922.

7. Leopoldini, M.; Russo, N.; Chiodo, S.; Toscano, M. Iron chelation by the powerful antioxidant flavonoid quercetin. J. Agric. Food Chem. 2006, 54, 6343-6351.

8. Leopoldini, M.; Russo, N.; Toscano, M. The molecular basis of working mechanism of natural polyphenolic antioxidants. Food Chem. 2011, 125, 288-305.

9. Nakanishi, I.; Miyazaki, K.; Shimada, T.; Ohkubo, K.; Urano, S.; Ikota, N.; Ozawa, T.; Fukuzumi, S.; Fukuhara, S. Effects of metal ions distinguishing between one-step hydrogen- and electron-transfer mechanisms for the radical-scavenging reaction of $(+)$-catechin. J. Phys. Chem. A 2002, 106, 11123-11126.

10. Waki, T.; Nakanishi, I.; Matsumoto, K.; Kitajima, J.; Chikuma, T.; Kobayashi, S. Key role of chemical hardness to compare 2,2-diphenyl-1-picrylhydrazyl radical scavenging power of flavone and flavanol O-glycoside and C-glycoside derivatives. Chem. Pharm. Bull. 2012, 60, 37-44.

11. Kobayashi, S.; Waki, T.; Nakanishi, I.; Matsumoto, K.; Anzai, K. Potent 2,2-diphenyl-1picrylhydrazyl radical-scavenging activity of novel antioxidants, double-stranded tyrosine residues conjugating pyrocatechol. Chem. Pharm. Bull. 2010, 58, 1442-1446.

12. Parr, R.G.; Pearson, R. Absolute hardness: Companion parameter to absolute electronegativity. J. Am. Chem. Soc. 1983, 105, 7512-7516.

13. Parr, R.G.; Yang, W. Density Functional Theory of Atoms and Molecules, 1st ed.; Oxford University Press: Oxford, UK, 1989.

14. Pearson, R. The principle of maximum hardness. Acc. Chem. Res. 1993, 26, 250-255.

15. Kobayashi, S.; Mizushima, A.; Sasuga, A.; Watanabe, M. Development of soft-based double-stranded peptide chelators which selectively separate europium and lanthanum ions based on the hardness concept. Chem. Pharm. Bull. 2006, 54, 761-763.

16. Kobayashi, S.; Watanabe, M.; Chikuma, T. Development of new double-stranded phenylalanyl chelators using $\eta-\chi$ diagrams and binding constants for chelators and lanthanide ions. Chem. Pharm. Bull. 2010, 58, 620-627.

17. Kuroda, Y.; Kawahara, M. Aggregation of Amyloid $\beta$-protein and its neurotoxicity: Enhancement by aluminum and other metals. Tohoku J. Exp. Med. 1994, 174, 263-268. 
18. Bernstein, S.L.; Dupuis, N.F.; Lazo, N.D.; Wyttenbach, T.; Condron, M.M.; Bitan, G.; Teplow, D.B.; Shea, J.-E.; Ruotolo, B.T.; Robinson, C.V.; et al. Amyloid- $\beta$ protein oligomerization and the importance of tetramers and dodecamers in the aetiology of Alzheimer's disease. Nat. Chem. 2009, 1, 326-331.

19. Shimomura, O.; Wu, C.; Murai, A.; Nakamura, H. Evaluation of five imidazopyrazione-type chemiluminescent superoxide probs and their application to the measurement of superoxide anion generated by listeria monocytogenes. Anal. Biochem. 1998, 258, 923-235.

20. Rajkumar, D.V.; Rao, M.N.A. Antioxidant properties of phenylstyryl ketones. Free Radic. Res. 1995, 22, 309-317.

21. Kobayashi, S.; Atuchi, N.; Kobayashi, H.; Shiraishi, A.; Hamashima, H.; Tanaka, A. Diastereomer selective effects for growth inhibition of synthesized mini parallel double-stranded peptides on Escherichia coli and Staphylococcus aureus. Chem. Pharm. Bull. 2004, 52, 204-213.

22. Milton, N.G. Role of hydrogen peroxide in the aetiology of Alzheimer's disease: Implications for treatment. Drugs Aging 2004, 21, 81-100.

23. Lebedev, A.V.; Ivanova, M.V.; Timoshin, A.A.; Ruuge, E.K. Effect of group II metal cation on catecholate oxidation. ChemPhysChem 2007, 8, 186-1869.

24. Asano, T.; Wang, P.-C.; Iwasaki, A. Synthesis of porphyrin-incorporated polymers and their application for simultaneous detection of multimetal components by using spectrophotometry. Spectrochim. Acta Part A Mol. Biomol. Spectrosc. 2010, 75, 305-309.

25. Asano, T. Development of the analytical method of heavy metals using the UV/Vis absorption characteristics of porphirin. Ph.D. Thesis, University of Tsukuba, Ibaraki, Japan, March 2010. Available online: http://www.tulips.tsukuba.ac.jp/limedio/dlam/B29/B2959292/1.pdf (accessed on 20 December 2012).

26. Hay, P.J.; Walt, W.E. Ab initio effective core potentials for molecular calculations. Potentials for the transition metal atoms Sc to Hg. J. Chem. Phys. 1985, 82, 270-283.

Sample Availability: Samples of the compounds $\mathbf{8 a}$ and $\mathbf{8 b}$ are available from the authors.

(C) 2013 by the authors; licensee MDPI, Basel, Switzerland. This article is an open access article distributed under the terms and conditions of the Creative Commons Attribution license (http://creativecommons.org/licenses/by/3.0/). 